\title{
Kanyouku Dengan Unsur Tumbuhan Pada Media Sosial Twitter
}

\author{
I Gusti Ngurah Dwija Parnatha ${ }^{1 *}$, I Made Budiana ${ }^{2}$, Renny Anggraeny ${ }^{3}$ \\ ${ }^{[1,2,3]}$ Program Studi Sastra Jepang Fakultas Ilmu Budaya Universitas Udayana \\ Denpasar Bali \\ Email: ${ }^{1}$ dwijaparnatha@gmail.com], ${ }^{2}$ [budi.hybrid@unud.ac.id], \\ 3 [renny_anggraeny@unud.ac.id]
}

\begin{abstract}
Abstrak
Penelitian ini hanya membahas makna, jenis dan proses pembentukan kanyouku dengan unsur tumbuhan menggunakan postingan di twitter dari pengguna orang Jepang pada tahun 2020 sebagai sumber data. Penelitian ini menggunakan teori pembentukan idiom dari Miharu dan teori semantik dari Chaer yang didukung oleh makna kanyouku oleh Inoue. Pengumpulan data pada penelitian ini digunakan metode simak yaitu dengan menyimak penggunaan bahasa pada media sosial twitter. Hasil yang diperoleh dalam penelitian ini yaitu pertama, makna leksikal kanyouku dengan unsur tumbuhan pada media sosial twitter terdiri dari makna leksikal ki, hana, kusa, take, sakura, momiji. Makna leksikal yang paling banyak digunakan yaitu Hana. Kedua, berdasarkan arti dan makna idiomatikalnya terbagi menjadi lima jenis makna idiomatikal yaitu, 1) Makna kanyouku yang menyatakan indera perasaan atau emosi, 2) Makna kanyouku yang menyatakan watak/sifat, keadaan tubuh, sikap/perilaku, 3) Makna kanyouku yang menyatakan tindakan, kelakuan, dan gerak, 4) Makna kanyouku yang menyatakan tingkatan, kondisi, dan harga atau nilai, 5) Makna kanyouku yang menyatakan kebudayaan, masyarakat, dan kehidupan. Ketiga, terdapat tiga cara pembentukan idiom unsur tumbuhan pada media sosial twitter yaitu idiom verba, idiom nomina, dan idiom adjektiva. Keempat, terdapat kanyouku dengan dua makna idiomatikal yang berbeda yaitu kanyouku kime ga komakai. Kelima, terdapat kanyouku yang berbeda tetapi memiliki makna idiomatikal yang sama yaitu kanyouku hatake suiren dan ki ni yorite sakana o тототи.
\end{abstract}

Kata kunci: Kanyouku, twitter, makna

\begin{abstract}
This study only determine the meaning, type and process of forming plant based kanyouku using posts on Twitter from Japanese users in 2020 as a data source. This research used kanyouku formation theory from Miharu and the semantic theory from Chaer which is supported by kanyouku meaning by Inoue. The data accumulation method used in this research is the observation method, by observing the use of language on Social Media Twitter. Then, the methods used in data analysis are the split method and the equivalent method.. The results obtained in this study are first, based on the lexical meaning of plant based kanyouku on Twitter social media consists of the lexical meanings of ki, hana, kusa, take, sakura, momiji. The most used lexical meaning is Hana. Second, based on the idiomatic meaning, it is divided into five types of idiomatic meaning, namely, 1) the meaning of kanyouku which state the senses of feeling or emotion, 2) the meaning of kanyouku which state the state of the body, nature/character, behavior/attitudes, 3) the meaning of kanyouku which state behavior, motion, and actions, 4) the meaning of kanyouku which state conditions, levels and values or prices, 5) the meaning of kanyouku which state society, culture, and life. Third, there are three ways to form plant based kanyouku on Twitter social media, namely verb idioms, noun idioms, and adjective idioms. Fourth, there is kanyouku with two different idiomatic meaning, namely kime ga komakai idiom. Fifth, there are different kanyouku while having the same idiomatical meaning, namely hatake suiren and ki ni yorite sakana o motomu kanyouku.
\end{abstract}

Keywords: Kanyouku; Twitter; Meanings, 


\section{Pendahuluan}

Kanyouku (慣用句) dalam bahasa Indonesia diartikan sebagai idiom, yang memiliki peran penting dalam komunikasi sehari-hari. Terdapat 6 jenis kanyouku, diantaranya kanyouku yang menggunakan unsur bilangan, hewan, tumbuhan, warna, angka, dan alam. Miharu (2003:124) membagi pembentukan kanyouku tersebut menjadi tiga, yaitu idiom verba(kata kerja), idiom adjektiva(kata sifat), dan idiom nomina (kata benda), yang mana dalam penelitian ini dianalisis ketiga pembentukan idiom tersebut. Penelitian ini dianalisis makna leksikal dan idiomatikal kanyouku yang difokuskan pada unsur tumbuhan yang merupakan salah satu dari unsur pembentukan kanyouku. Penggunaan kanyouku tidak hanya digunakan pada percakapan sehari-hari, pada media sosial juga dimuat pesan-pesan yang muncul menggunakan kanyouku, khususnya kanyouku dengan unsur tumbuhan. Oleh sebab itu, sumber data yang dijadikan dalam penelitian ini yaitu media sosial, khususnya pada media sosial Twitter.

Berdasarkan latar belakang yang dipaparkan, terdapat dua masalah yang dapat dirumuskan, yaitu sebagai berikut:

a) Bagaimanakah makna leksikal yang terbentuk dari kanyouku yang menggunakan unsur tumbuhan dalam media sosial twitter?

b) Bagaimanakah makna idiomatikal yang terbentuk dari kanyouku yang menggunakan unsur tumbuhan dalam media sosial twitter?

c) Bagaimanakah pembentukan kanyouku yang menggunakan unsur tumbuhan dalam bahasa Jepang di media sosial twitter?

\section{Metode dan Teori}

\subsection{Metode Penelitian}

Penelitian ini menggunakan metode simak pada tahap pengumpulan data . selanjutnya digunakan metode agih dan metode padan referensial pada analisis data. Terakhir, digunakan metode informal formal dan pada tahap penyajian data.

\subsection{Teori}

Teori yang digunakan yaitu pertama, teori semantik oleh Chaer (2013) dan teori makna kanyouku oleh Inoue (1992) digunakan untuk menganilisis makna leksikal dan idiomatikal dari kanyouku yang mengandung unsur tumbuhan. Kedua, teori pembentukan 
idiom dari Miharu (2003) yang digunakan untuk menganalisis pembentukan kanyouku yang mengandung unsur tumbuhan. Analisis pertama dilakukan untuk mengetahui proses pembentukan kata idiom yang menggunakan unsur tumbuhan menggunakan teori pembentukan idiom oleh Miharu (2003). Analisis kedua dilakukan untuk mengetahui makna yang terdapat dalam idiom tersebut dengan menggunakan teori semantik dari Chaer (2014) yang didukung oleh teori klasifikasi (arti dan makna) idiom dari Inoue (1992). Awalnya menganalisis makna leksikal dari setiap kata pembentuk dari idiom tersebut. Kemudian, setelah makna leksikal selesai dianalisis maka selanjutnya menganalisis makna idiomatikal, serta mengklasifikasikan idiom tersebut

\section{Kajian Pustaka}

Kajian pustaka terdiri dari penelitian-penelitian yang berkaitan dengan penelitian ini. Ada pun penelitian tersebut yaitu sebagai berikut.

Halil (2015) dalam penelitiannya berjudul “Analisis Makna Kanyouku yang Menggunakan Nama Bagian Tubuh pada Komik Chibi Maruko Chan Kanyouku Kyoushitsu Karya Kawashima Yutaka". Teori yang digunakannya adalah teori doushi kanyouku, keiyoushi kanyouku, meishi kanyouku dan teori semantik. Penyajian data yang telah dikumpulkan dianalisis menggunakan metode deskriptif. Hasil analisis dari penelitian Halil menunjukkan bahwa terdapat 20 data idiom dalam Komik Chibi Maruko Chan Kanyouku Kyoushitsu karya Kawashima Yutaka dan terdiri dari empat data termasuk keiyoushi kanyouku dan enam belas data termasuk doushi kanyouku.

Permatasari (2017) dalam penelitiannya yang berjudul "Idiom Bahasa Jepang yang Menggunakan Nama Hewan" dianalisis mengenai idiom yang menggunakan unsur hewan dalam bahasa jepang. Teori yang digunakan yaitu teori makna, bentuk, dan klasifikasi idiom". Metode penyajian hasil analisis data digunakan metode informal. Hasil dari penelitian Permatasari ditemukan 39 idiom yang menggunakan nama hewan dan masih digunakan hingga sekarang.

\section{Hasil dan Pembahasan}

Penjabaran makna leksikal, makna idiomatikal, dan pembentukan kanyouku yang terbentuk dari unsur tumbuhan, selanjutnya diuraikan menjadi seperti berikut: 


\subsection{Makna Kanyouku yang Menyatakan Indera Perasaan atau Emosi}

Berikut data yang menunjukkan kanyouku berunsur tumbuhan yang menyatakan indera perasaan atau emosi atau dalam bahasa Jepang disebut dengan kankoku, kanji o arawasu kanyouku.

(1)@hntzk

この 1 年間、クラスでは業務連絡以外誰とも会話してません みんな私が高嶺の花すぎて話しかけられないのかな

もっともっと儚くなろっと

'Kono ishuukan, kurasu de wa gyōmu renraku igai dareto mo kaiwa shitemasen Minna watashi ga takane no hana sugite hanashikakerarenai no ka na

Motto motto hakanaku narotto

'Selama satu tahun ini, aku tidak pernah berbicara dengan siapapun selain urusan bisnis.

Apakah aku terlalu takane no hana sehingga aku tidak mampu untuk memulai percakapan

Jadi semakin fana'

(13/01/2020 diakses dari Twitter)

Data (1) terlihat tulisan dari salah satu pengguna twitter yang menyampaikan bahwa akhir-akhir ini ia tidak mampu memulai percakapan. Iapun mengatakan bahwa dirinya terlalu takane no hana terhadap situasi tersebut. Takane no hana merupakan kanyouku berunsur tumbuhan, yang secara leksikal berarti bunga yang tinggi. Namun apabila diartikan secara idiomatikal, diibaratkan seperti bunga yang indah namun sulit untuk kita gapai, hal indah yang sulit dicapai, sesuatu yang tidak dapat kita ambil dan miliki hanya dengan melihatnya dari kejauhan. Sehingga memiliki makna keputusasaan.

Berikut penjabaran dari pembentukan kanyouku takane no hana dilihat dari strukur pembentukannya.

$$
\begin{aligned}
& \begin{array}{l}
\text { Takane }+ \text { no }+ \text { Hana } \\
(N)+P A R+(N)
\end{array} \rightarrow \begin{array}{l}
\text { Takane no hana } \\
(\text { idiom } N+N)
\end{array}
\end{aligned}
$$

\subsection{Makna Kanyouku yang Menyatakan Watak/Sifat, Keadaan Tubuh, Sikap/Perilaku}

Berikut data-data yang menunjukkan kanyouku yang menyatakan indera perasaan atau emosi dalam bahasa Jepang disebut dengan , karada, taido o arawasu kanyouku.

(2)@SJ18J9HMISdOgGZ

私、うつ病で休職中に雇い止めになったんだよね。で、やっぱ仕事なくな るってめちゃくちゃ動摇してめっちゃ調子悪くなったの。でも友達に嫌な 会社とお別れできてスッキリじゃんって言われてさ。そうかって思ったら なんか重たいの 1 個取れて少しラクに感じたの。

Watashi, utsubyou de kyūshoku-chū ni yatoidome ni nattanda yo ne. De, yappa shigoto nakunaru tte mechakucha dōyō shite meccha chōshi waruku natta no. Demo 
tomodachi ni iyana kaisha to o wakare dekite sukkirijan tte iwarete sa. Souka tte omottara nanka omotai no iko torete sukoshi raku ni kanjita no.

Saya, diberhentikan sementara dari perusahaan karena mengalami depresi. Lalu, bagaimanapun, saya sangat kesal karena saya tidak bekerja dan kondisi saya memburuk. Tetapi teman saya mengatakan kepada saya bahwa sangat menyegarkan bisa pergi dari perusahaan yang tidak saya sukai. Ketika saya berpikir demikian, salah satu beban saya berkurang dan merasa sedikit lebih ringan.

@imsomniaionarap

そっかあ〜、確かに嫌な会社とお別れできてハッピーっすね!お友達さん いい人ですね

Sokka a , tashika ni iyana kaisha to o wakare dekite happissu ne! O tomodachi-san ii hito desu ne

Oh begitu, saya yakin pasti senang rasanya bisa mengucapkan selamat tinggal kepada perusahaan yang tidak menyenangkan! Temanmu baik ya

@SJ18J9HMISdOgGZ

竹を割ったような性格の友達です

Take o watta you na seikaku no tomodachi desu

Teman yang memiliki sifat take o watta you

(12/04/2020 diakses dari Twitter)

Data (2) terlihat percakapan antara 2 pengguna twitter yang mengeluhkan tentang pekerjaannya. Salah satu teman yang sedang mengeluhkan pekerjaannya tersebut diberitahu oleh seorang temannya untuk lebih baik berhenti bekerja apabila tidak menyukai suatu perusahaan tersebut. Salah satu pengguna twitter membalas bahwa temannya tersebut memiliki sifat take o watta you, yang mana diartikan memiliki sifat yang tegas, mengatakan langsung apa yang dipikirkannya demi kebaikan temannya tersebut.

Take o watta you merupakan kanyouku berunsur tumbuhan, yang secara leksikal berarti seperti bamboo yang dibelah. Namun apabila diartikan secara idiomatikal, diibaratkan seperti bamboo yang dibelah memanjang rapi menjadi dua. Dikarenakan bambu yang dibelah rapi dan bersih menjadi dua, diartikan seperti orang yang berkata jujur, apa adanya, tanpa dibuat-buat, tidak ada kejanggalan, dan tidak ada keburukan dalam temperamen. Sehingga memiliki makna sifat yang jujur, tegas.

Take o watta you dilihat dari strukur pembentukannya terdiri dari Noun (kata benda) + Verb (kata kerja). Berikut penjabaran dari pembentukan kanyouku take o watta you:

$$
\begin{array}{ll}
\text { Take }+o+\text { watta you } \\
(N)+P A R+(V)
\end{array} \rightarrow \begin{aligned}
& \text { Take o watta you } \\
& (\text { idiom } N+V)
\end{aligned}
$$


(3) @ matsui_ai_1828

午後からは、市民連合山形市議団の先輩たちと第 3 回目の \#新型コロナ ウイルス 対策会議。

13 時から開かれた産業文教委員会の勉強会の報告を受け、今後の対応の あり方について議論しました。

Gogo kara wa, shimin Rengou Yamagata shigidan no senpai tachi to dai 3 kai me no \#shingata koronauirusu taisaku kaigi.

13ji kara akareta sangyou bunkyou iinkai no benkyoukai no houkoku o uke, kongo no taiou no arikata ni tsuite giron shimashita.

Dari sore hari, \#Konferensi Penanggulangan Corona Vvirus Baru yang ke-3 diadakan dengan para senior dari Dewan Persatuan Warga Kota Yamagata.

Kami menerima laporan dari sesi studi Panitia Pendidikan Industri yang diadakan mulai pukul 13.00 dan membahas bagaimana menyikapinya kedepannya.

@nayu1110

お疲れ様です。とても木目が細かい対応だと思いました。皆さんの山形 をなんとかせねばという気持ちが伝わりました。有り難うございます。 佐藤議員は選挙の時マニフェストを見て、即決投票しました 佐藤秀明議員に伝えますね!

Otsukaresamadesu. Totemo kime ga komakai taiou da to omoimashita. Minasan no Yamagata o nantoka seneba to iu kimochi ga tsutawarimashita. Arigatou gozaimasu.

Satou giin wa senkyo no toki manifesuto o mite, sokketsu touhyou shimashita satou hideaki giin ni tsutaemasu ne!

Terima kasih atas kerja kerasnya(Otsukaresama!). Saya pikir itu adalah respon yang sangat kime ga komakai. Saya bisa seperti merasakan perasaan bahwa setiap orang harus melakukan sesuatu terhadap Yamagata. Terima kasih.

Perwakilan Sato melihat manifesto pada saat pemilihan dan segera memberikan suara

Sampaikan kepada Anggota Kongres Hideaki Sato!

@matsui_ai_1828

佐藤秀明議員に伝えますね!

彼は山形市政になくてはならない議員です。お世辞抜きで心からそう思 います！私もそんな風に思ってもらえる議員目指して頑張ります。

Satō hideaki giin ni tsutaemasu ne!

Kare wa Yamagata shisei ni nakute wa naranai giindesu. Oseji nuki de kokoro kara sou omoimasu! Watashi mo sonna funni omotte moraeru giin mezashite ganbarimasu.

Akan aku sampaikan ke anggota kongres Hedeaki Sato!

Dia adalah anggota yang sangat diperlukan dalam pemerintahan kota Yamagata. Sayapun bepikir begitu dari lubuk hati saya! Saya juga berpikir demikian, saya akan melakukan yang terbaik untuk menjadi anggota kongres

(14/4/2020 diakses dari Twitter)

(4)@miho_dotdotdot

今日は美容室とネイルサロンへ。髪の毛けっこう短くしました一新鮮カ ラーは後日爪はいつも短いです。ネイリストさん泣かせ前にイベントで 質問いただいたことあるけど、弦楽器だけどネイル楽しみたい派なので す 


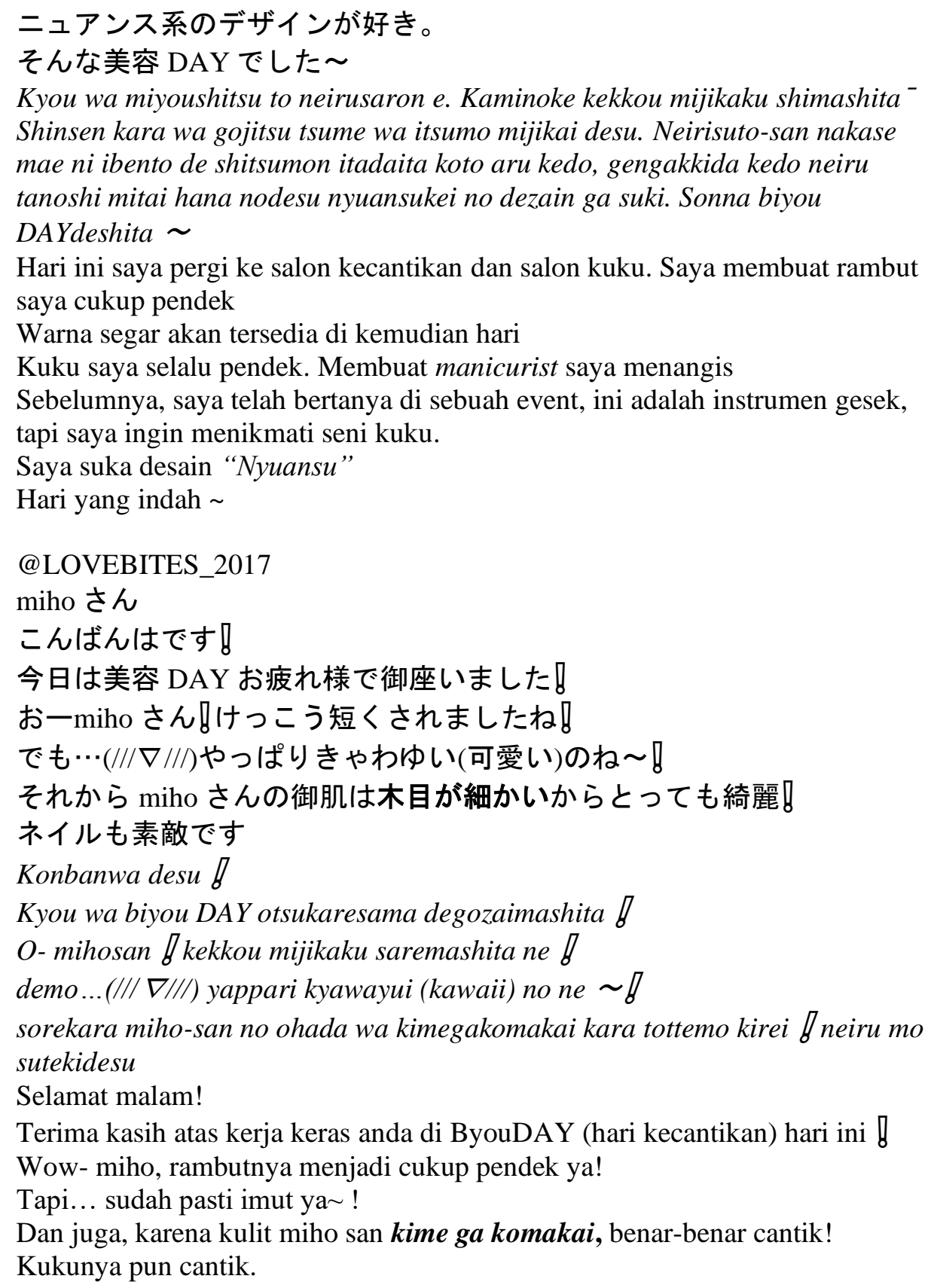

(6/1/2020 diakses dari Twitter)

Kanyouku kime ga komakai memiliki 2 arti yang berbeda apabila digunakan dengan konteks yang berbeda. Kime ga komakai awalnya merupakan istilah yang berarti kayu (mokume/xylem) dari pohon yang dipotong seperti papan dan tiang kayu dengan kualitas yang baik dan teksturnya yang halus. Jika kanyouku ini diterapkan pada kulit manusia, maka akan menjadi kulit yang "halus". Lalu seiring dengan berjalannya waktu, "kime ga komakai" telah berkembang lebih jauh, dan telah diterapkan pada cara kerja dan cara memproses sesuatu. Dalam konteks ini, "kime ga komakai", dapat berarti "teliti, detail, dan juga cermat". 
Data (3) terlihat percakapan dua pengguna twitter yang sedang membahas mengenai konfrensi penanggulangan corona virus baru yang ke tiga. @matsui_ai_1828 yang saat itu sedang mengungah foto dirinya yang sedang mengikuti konfrensi penanggulangan corona virus baru yang ke 3 beserta berkas-berkas yang sudah tercoratcoret dengan catatan-catatan kecil. @ nayu1110 melalui akun Twitternya, kemudian menmberikan apresiasi atas kerja kerasnya selama mengikuti konfrensi tersebut dengan mengatakan "tottemo kime ga komakai". Oleh karena itu kanyouku ini memiliki makna teliti, cermat. Sedangkan, data (4) terlihat @miho_dotdotdot mengunggah foto rambut baru dan kukunya dalam rangka hari kecantikan. @LOVEBITES_2017 melalui akunnya, melihat perubahan pada rambut tersebut, dan juga menyebutkan bahwa kulit miho "kime ga komakai”, yang dalam konteks kalimat ini, berarti halus.

Berikut penjabaran dari pembentukan kanyouku kime no komakai dilihat dari strukur pembentukannya.

$$
\begin{aligned}
& \text { kime }+g a+\text { komakai } \rightarrow \text { Kime ga komakai } \\
& \text { (N) } \quad+P A R+\text { (Adj) (idiom } N+\text { Adj) }
\end{aligned}
$$

\subsection{Makna Kanyouku yang Menyatakan Tindakan, Kelakuan, Dan Gerak}

Berikut data-data yang menunjukkan kanyouku yang menyatakan kelakuan, gerak dan tindakan atau dalam bahasa Jepang disebut dengan koudou, koui, dousa o arawasu kanyouku.

(5)@lino31678

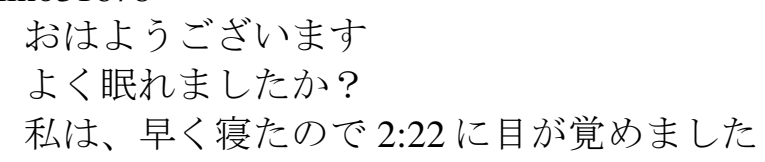

Ohayōgozaimasu

Yoku nemuremashita ka?

Watashi wa, hayaku neta node 2: 22 ni me ga samemashita

Shashin wa, kinou michi o sorete yotta 'michi no eki' kara no fükei desu ga, kodomo wa keshiki yori mo ichigo de shita. Yappari hana yori dango desu ne

Kodomo ga gakkō no toki wa okoshite mo nakanaka okinai no ni, yasumi no toki wa hayaku okiru! Kore tte nanidarou

Selamat pagi

Apakah anda tidur dengan nyenyak ?

Saya, karena tidur lebih cepat jadi bangun jam 2:22

Foto ini, adalah pemandangan dari "Jalan seputar stasiun kereta" dipersimpangan jalan kemarin, namun anak-anak lebih memilih strawberi dibandingkan pemandangan. Benar-benar hana yori dango 
Padahal anak-anak pada waktu sekolah dibangunkanpun tidak kunjung bangun, namun pada hari libur bangun lebih awal. Apa-apaan ini

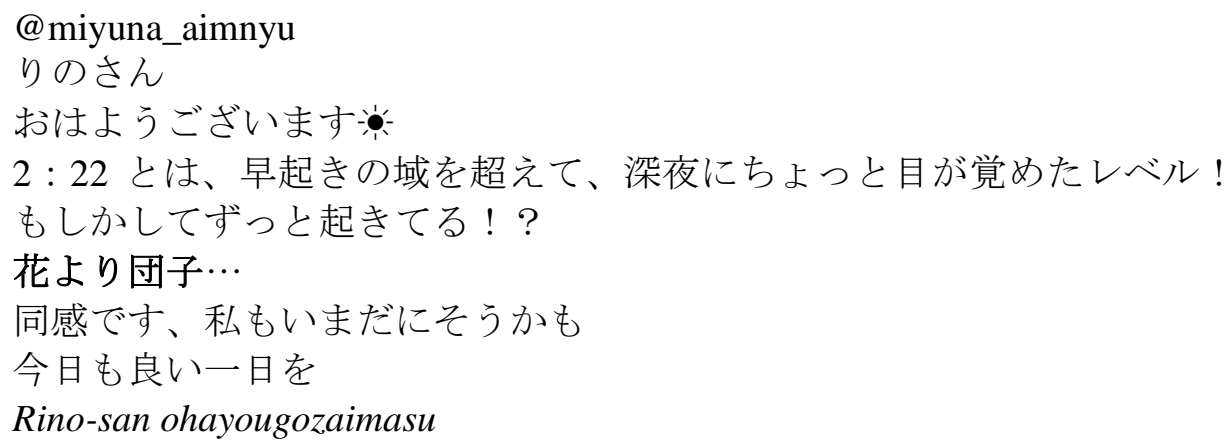
malam sedikit terbangun! Jangan-jangan anda selalu terjaga!?

Hana yori dango

Setuju, akupun mungkin sampai sekarang masih seperti itu Semoga harimu menyenangkan hari ini

(27/12/2020 diakses dari Twitter)

Data (5) terlihat percakapan dua pengguna twitter yang sedang membicarakan kegiatan berlibur yang baru dilalui. Salah seorang penggua twitter yang mempunyai anakanak, mengatakan bahwa di sepanjang perjalanan ia sangat menikmati pemandangan di sekitaran jalan stasiun kereta dan berhenti sejenak untuk mengambil gambar dari pemandangan tersebut. Namun, anak-anak justru lebih memilih stroberi dibandingkan dengan menikmati pemandangan indah tersebut. Hana yori dango merupakan kanyouku berunsur tumbuhan, yang secara leksikal berarti memilih dango dibanding bunga. Namun apabila diartikan secara idiomatikal, berarti daripada memilih sesuatu yang indah dilihat, lebih baik memilih sesuatu yang bermanfaat. Peribahasa ini terjadi karena kebiasaan orang jepang hanami (melihat bunga) di waktu sakura bermekaran di musim semi. Acara hanami ini menjadi ajang bersilaturahmi dengan teman-teman, dan kebanyakan bila sudah berkumpul, semua lebih memilih berbincang dan makan bersama teman dibandingkan melihat bunga.

Hana yori dango apabila dari strukur pembentukannya terdiri dari Noun (kata benda) + Noun (kata benda). Berikut penjabaran dari pembentukan kanyouku hana yori dango 


$$
\begin{aligned}
& \text { Hana + yori }+ \text { dango } \rightarrow \quad \text { Hana yori dango } \\
& (N)+\text { lebih dari }+(N) \quad \text { (idiom } N+N)
\end{aligned}
$$

Kanyouku hana yori dango termasuk ke dalam kelompok idiom nomina karena terbentuk dari nomina hana dan nomina dango. Kanyouku hana yori dango dihubungkan dengan yori yang berfungsi sebagai membandingkan nomina satu dengan nomina lainnya.

(6)@ @yoshimine

頼む、宇崎ちゃんポスター批判派で、宇崎ちゃん第二弾を批判している 人いないの? 本当に「問題点は解消された。よかった」みたいなのだ け?

批判している人がいないとしたら、あまりにも無茶苦茶なんだが.......。 Tanomu, Uzaki chan posutaa hihan hade, Uzaki chan dai ni dan o hihan shite iru hito inai no? Hontou ni 'mondaiten wa kaishou sareta. Yokatta' mitaina no dake? Hihan shite iru hito ga inai to shitara, amari ni mo muchakuchananda ga.......

Tolong, adakah yang mengkritik poster Uzaki-chan dan mengkritik edisi kedua Uzaki-chan? Benar-benar seperti "Masalah telah diselesaikan. Lega"? itu saja?

Jika tidak ada yang mengkritik, ini benar-benar gila

@ tamai1961

相手が理性的だと想定するのが「議論」の作法なのだと思いますが、 「木に緣りて魚を求む」虚しさを感じます。

Aite ga riseiteki da to soutei suru no ga 'giron' no sahōna noda to omoimasuga, 'ki ni yorite sakana o motomu' munashisa o kanjimasu

Menurut saya metode untuk mengasumsikan bahwa pihak lain itu rasional adalah menggunakan cara "diskusi", tetapi saya merasakan kekosongan "ki ni yorite sakana o motomu"

(02/02/2020 diakses dari Twitter)

Data (6) terdapat percakapan dua pengguna twitter yang sedang membahas mengenai salah satu karakter anime yaitu Uzaki-chan. @kyoshimine yang pada saat itu mengutarakan rasa kesal dan kecewa karena tidak ada yang mengkritik poster edisi ke 2 Uzaki-chan, dan mengatakan bahwa jika tidak ada yang mengkritik berarti benar-benar tidak masuk akal. @tamai1961 dalam akun twitter nya, menyampaikan bahwa, ada hal yang bagus untuk menyelesaikan masalah tersebut, yaitu dengan berdiskusi, namun iya mengatakan hal tersebut hanyalah "ki ni yorite sakana o motomu". Kanyouku ini secara leksikal berarti, mencari ikan dengan cara memanjat pohon. Namun jika diartikan secara idiomatikal, kanyouku ini berarti sia-sia, Hal tersebut dikarenakan, ikan hidup di air, kita tidak bisa mendapatkannya dengan memanjat pohon dan mencarinya di atas pohon.

Selain kanyouku ki ni yorite sakana o motomu, ditemukan kanyouku dengan makna yang sama yaitu kanyouku "hatake suiren". Kanyouku tersebut sama-sama 
memiliki arti sia-sia. Kanyouku “hatake suiren (畑水練)” memiliki makna belajar di daratan yaitu secara idiomatikal sebuah perumpamaan pada hal yang tidak berguna/ siasia.

Berikut penjabaran dari pembentukan kanyouku ki ni yorite sakana o motomu dilihat dari strukur pembentukannya

$$
\begin{aligned}
& K i+n i+\text { yorite }+ \text { sakana }+ \text { o+ motomu ki ni yorite sakana o motomu } \\
& (N)(P A R)+(v)+(N)+P A R+(V)
\end{aligned}
$$

\subsection{Makna Kanyouku yang Menyatakan Tingkatan, Kondisi, dan Harga atau} Nilai

Berikut data-data yang menunjukkan kanyouku berunsur tumbuhan yang menyatakan kondisi, tingkatan, nilai atau harga atau dalam bahasa Jepang disebut dengan joutai, teido, kachi o arawasu kanyouku.

(7)@vertigo0606

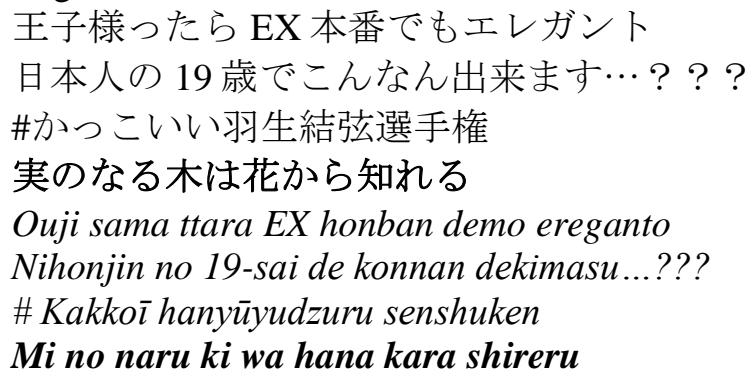
terlihat elegant

Orang jepang yang berusisa 19 tahun sudah bisa melakukan hal seperti ini ...? ?? ??

\#CoolYuzuruHanyuChampionship

Mi no naru ki wa hana kara shireru

@ pompomcotton

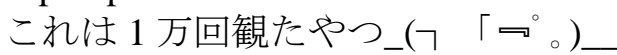

Kore wa 1 man-kai mita yatsu

Orang ini sudah aku tonton 10.000 kali

(4/4/2020 diakses dari Twitter)

Data (7) terlihat bahwa salah satu pengguna twitter@vertigo0606 menuliskan kekagumannya pada salah seorang pangeran dalam sebuah perlombaan Yuzuru Hanyu. Ia menuliskan kekagumannya karena pada usia 19 tahun, pangeran yang ia tuliskan di tautan twitternya sudah mampu melakukan hal-hal hebat. Ia lalu mengatakan bahwa pangeran tersebut adalah mi no naru ki wa hana kara shireru. Hal tersebut pun didukung oleh salah 
satu balasan dari salah satu temannya yang menuliskan bahwa dirinya juga sudah menonton pangeran tersebut hingga ribuan kali.

Mi no naru ki wa hana kara shireru secara leksikal berarti bakal buah bisa dilihat dari bunganya. Secara idiomatikal, hampir sama dengan makna aslinya, diibaratkan buahbuahan terlihat dari munculnya bunga-bunga yang bermekaran. Biasanya sebuah pohon yang memiliki bunga yang indah, dapat dipastikan memiliki buah yang baik, begitu juga sebaliknya. Oleh karena itu kanyouku ini memiliki makna makna yaitu orang sukses biasanya sudah terlihat sejak masih usia belia.

Berikut penjabaran dari pembentukan kanyouku mi ni naru ki wa hana kara shireru dilihat dari strukur pembentukannya.

$$
\begin{aligned}
& m i+n o+n a r u+k i+w a+\text { hana }+ \text { kara }+ \text { shireru } \\
& (\mathrm{N})+\mathrm{PAR}+(\mathrm{V})+(\mathrm{N}) \mathrm{PAR}+(\mathrm{N})+\mathrm{PAR}+(\mathrm{V})
\end{aligned}
$$

Kanyouku ini merupakan kelompok idiom verba karena terbentuk dari nomina $m i$, nomina hana dan verba naru dan tsugu. kanyouku Mi no naru ki wa hana kara shireru dihubungkan partikel penunjuk suatu kejadian $n i$ dan wa partikel penanda subjek.

\subsection{Makna Kanyouku yang Menyatakan Kebudayaan, Masyarakat, dan Kehidupan}

Berikut data-data yang menunjukkan kanyouku berunsur tumbuhan yang menyatakan masyarakat, kebudayaan, dan kehidupan dan dalam bahasa Jepang disebut dengan bunka, shakai, seikatsu o arawasu kanyouku.

(8)@chihiro_dayoon

歳を重ねると、大切な人や物との別れとか、大きな喪失感を抱くことが たまにありますよね。

中学の時は理解できなかった『花に嵐のたとえもある』が沁みる。 全てのさよならまでに、どれだけの優しさと愛情を積めるか。愛と優し さは時に努力でもある

Toshi o kasaneru to, taisetsuna hito ya mono to no wakare toka, ōkina soushitsukan o daku koto ga tamani arimasu yo ne.

Chūgaku no toki wa rikai dekinakatta "hana ni arashi no tatoe mo aru" ga shimiru.

Subete no sayonara made ni, dore dake no yasashi-sa to aijou o tsumeru ka. Ai to yasashisa wa toki ni doryoku de mo aru

Seiring bertambahnya usia, terkadang kita merasakan kehilangan yang sangat besar, seperti berpisah dengan orang yang dicintai dan hal-hal lain.

Saat saya masih sekolah menengah pertama, saya tidak bisa mengerti "Ada perumpamaan tentang hana ni arashi. " 
Sampai saatnya mengucapkan selamat tinggal nanti, berapa banyak kebaikan dan kasih sayang yang bisa anda kumpulkan ? Cinta dan kasih sayang juga terkadang memerlukan usaha

@utsusemimaru_07

大切なものとの

別れは辛いですね。

者でも物でも思いが 1 番です>.く

Taisetsuna mono to no

wakare wa tsuraidesu ne.

Mono demo mono demo omoi ga ichiban desu >.<

Dengan hal-hal yang penting

Sangat sulit untuk mengucapkan selamat tinggal

Perasaanku akan entah itu orang ataupun benda adalah hal yang paling utama

@chihiro_dayoon

ほんとほんと、でもまあまた積み上げて頑張ります

Honto honto, demo maa mata tsumiagete ganbarimasu

Sungguh, tapi yaah aku akan melakukan yang terbaik lagi untuk memupuk halhal tersebut

(12/11/2020 diakses dari Twitter)

Data (8) terlihat percakapan antara 2 pengguna twitter, (1) @ chihiro_dayoon yang dulunya pernah mendengar sebuah kanyouku yang mengatakan bahwa hana ni arashi. Akan tetapi pada saat itu dirinya sama-sekali tidak mengerti apa arti dari kanyouku tersebut. Lalu seiring berjalannya waktu, dirinya mulai menyadari bahwa kanyouku hana ni arashi yang berarti penghalang, mulai ia rasakan. Begitupun juga balasan dari tautan tersebut yang mengatakan bagaiman ia tidak siap apabila terdapat halangan atau hal buruk terjadi padanya.

Hana ni arashi merupakan versi singkat dari tsuki ni muragumo, hana ni arashi, yang secara harfiah diterjemahkan, "Awan di atas bulan, badai di atas bunga". Seringkali kemalangan membayangi bahkan di saat-saat paling membahagiakan. Oleh karena itu kanyouku ini memiliki makna makna penghalang/ hal buruk datang di saat semuanya baik-baik saja.

Berikut penjabaran dari pembentukan kanyouku hana ni arashi dilihat dari strukur pembentukannya
Hana $+n i+$ arash $i$
(N) + PAR $+(\mathrm{N})$
$\rightarrow \quad$ Hana ni arashi
$($ idiom $N+N)$ 


\section{Simpulan dan Saran}

Berdasarkan analisis delapan data dengan tujuh idiom dengan unsur tumbuhan pada media sosial twitter, terdapat lima hal yang dapat disimpulkan. Pertama, makna leksikal kanyouku dengan unsur tumbuhan pada media sosial twitter terdiri dari makna leksikal $k i$, hana, kusa, take, sakura. Makna leksikal yang paling banyak digunakan yaitu Hana. Kedua, berdasarkan arti dan makna idiomatikalnya terbagi menjadi lima jenis makna idiomatikal yaitu, , 1) makna kanyouku yang menyatakan indera perasaan atau emosi, 2) makna kanyouku yang menyatakan watak/sifat, keadaan tubuh, sikap/perilaku, 3) makna kanyouku yang menyatakan tindakan, kelakuan, dan gerak, 4) makna kanyouku yang menyatakan tingkatan, kondisi, dan harga atau nilai, 5) makna kanyouku yang menyatakan kebudayaan, masyarakat, dan kehidupan. Ketiga, terdapat tiga cara pembentukan idiom unsur tumbuhan pada media sosial twitter yaitu idiom verba, idiom nomina, dan idiom adjektiva. Keempat, terdapat kanyouku dengan dua makna idiomatikal yang berbeda yaitu kanyouku kime ga komakai. Kelima, terdapat kanyouku yang berbeda tetapi memiliki makna idiomatikal yang sama yaitu kanyouku hatake suiren dan ki ni yorite sakana o motomu.

\section{Daftar Pustaka}

Badri, Muhammad. 2011. Corporate and Marketing Communication. Jakarta: Universitas Mercu Buana

Chaer, Abdul. 1990. Pengantar Semantik Bahasa Indonesia. Jakarta: Rineka. Cipta.

Chaer, Abdul. 2014. Linguistik Umum. Jakarta: Rineka Cipta.

Djajasudarma, Fatimah. 1999. Pengantar Kearah Ilmu Makna. Bandung :Refika

AditamaMuneo, Inoue. (1992). Reikai Kanyouku Jiten. Tokyo: Sotakusha.

Miharu, Akimoto. 2003. Yoku Wakaru Goi. Tokyo; ALC 